\title{
Desert kites in the Libyan Sahara: new evidence from remotely sensed images
}

\author{
Gianna Giannelli ${ }^{1, *} \&$ Fabio Maestrucci ${ }^{1}$
}

Satellite imagery analysis has revealed the presence of at least 330 stone structures-akin to 'desert kites' recorded elsewhere-on and around the Hamada al Hamra Platean in Libya. These structures, which probably vary in shape based on local geomorphology, may have been used for hunting or herding animals.

\section{Introduction}

The discovery of numerous stone structures in Northern Africa-possibly intended to catch wild animals or to gather semi-domestic or domestic species-is providing new information concerning ancient subsistence strategies. Research using satellite imagery of stone structures on the Hamada al Hamra Plateau in Libya and neighbouring areas (Figure 1) has thus far identified 330 such structures. These are characterised by architectural analogy with the socalled 'desert kites' observed mainly in the Middle East and South-west Asia. The Libyan structures, although lacking a polygonal enclosure with cells, stand out in their significant variety of shapes, which is probably related to the morphology of the territory and the species of fauna that they were intended to detain.

\section{Desert kite typology}

The structures are mainly concentrated on the western (about 60 per cent) and north-eastern (about 30 per cent) borders of the plateau, in areas once frequented by prey animals. Examples at the western edge of the Hamada consist of a pair of converging V-shaped walls, where the natural limit of the escarpment forms an integral part of the trap (Figure 2). These types of desert kites have similarities with the 'headland kites' on the Ustyurt Plateau of Kazakhstan (Betts \& Yagodin 2000; Barge et al. 2016). We also note a frequency of structures with a ' $\mathrm{V}$ ' shape that seem either to have blocked or circumscribed an area to facilitate the movement, control or capture of prey animals. The geomorphological diversity of the eastern Hamada slope seems to be reflected in the architectural variety of desert kitesthe geometry and extent of their antennae is particularly characteristic (Figure 3).

Capture systems known as 'chutes' are prevalent, with architectural similarities to those identified in the Negev and Sinai Deserts (Holzer et al. 2010; Bar-Oz et al. 2011; Nadel et al. $2010,2013)$. The walls converge to the edge of a slope or a step, with the intention of forcing prey into a natural pit or an artificial stone enclosure (Figure 4: top \& centre). One of these complexes-built on a long and narrow tabular promontory-is accompanied by two

1 v.le Giotto 7, 50053 Empoli, Florence, Italy

* Author for correspondence (Email: ggfmae@alice.it)

(c) Antiquity Publications Ltd, 2018 ANTIQUITY 92 364, e3 (2018): 1-7 


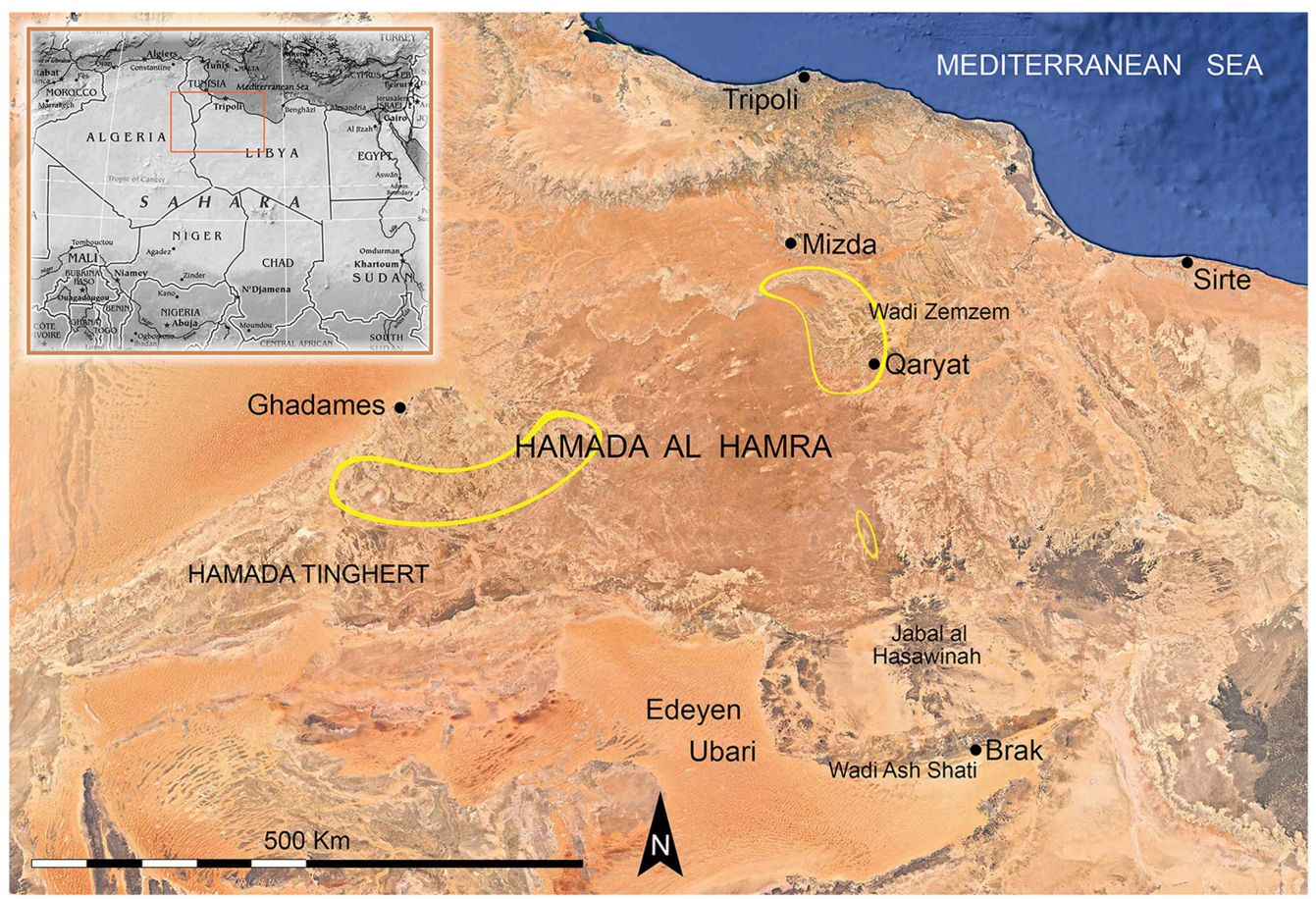

Figure 1. Three main areas (yellow) of structure distribution on the Hamada al Hamra Platean (image (C) Google Earth).

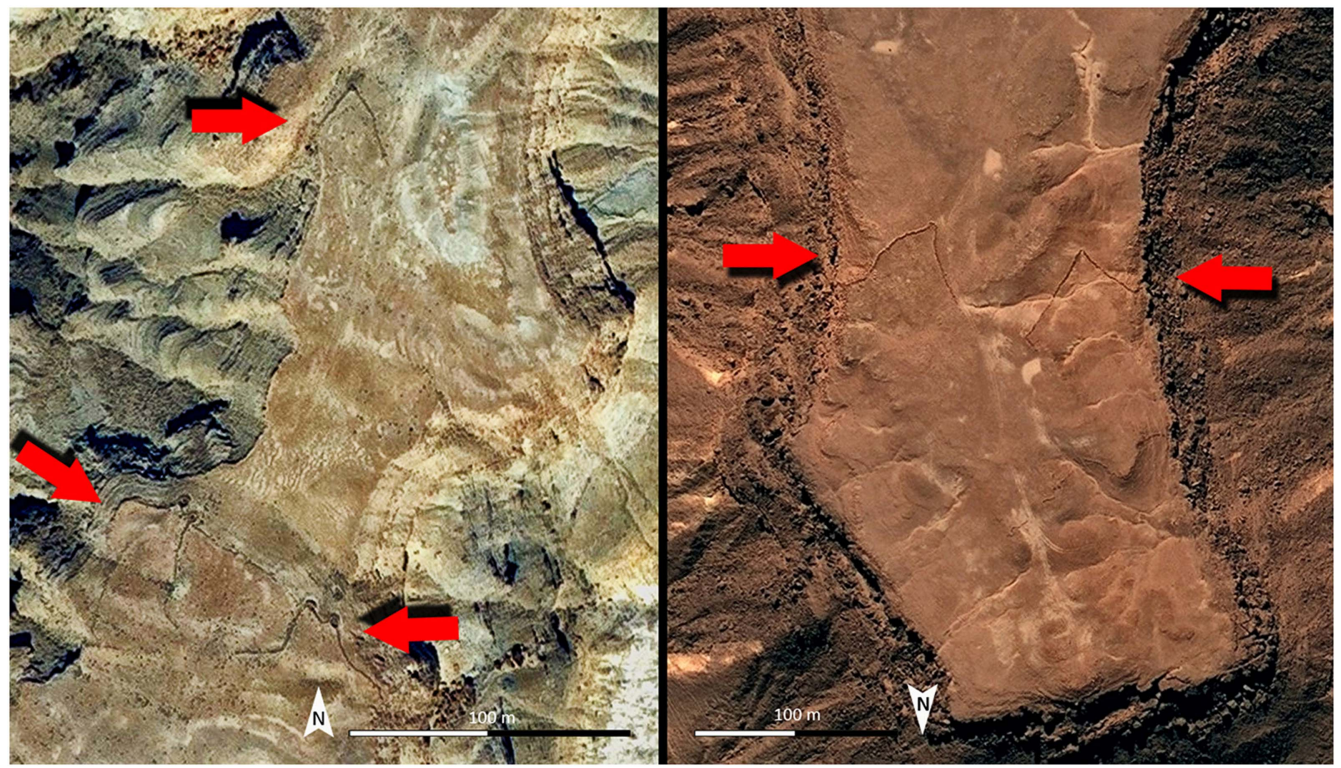

Figure 2. Comparing satellite images of a headland kite on the Ustyurt Plateau (left) and a Hamada al Hamra kite (right) (images (C) Google Earth).

(c) Antiquity Publications Ltd, 2018 

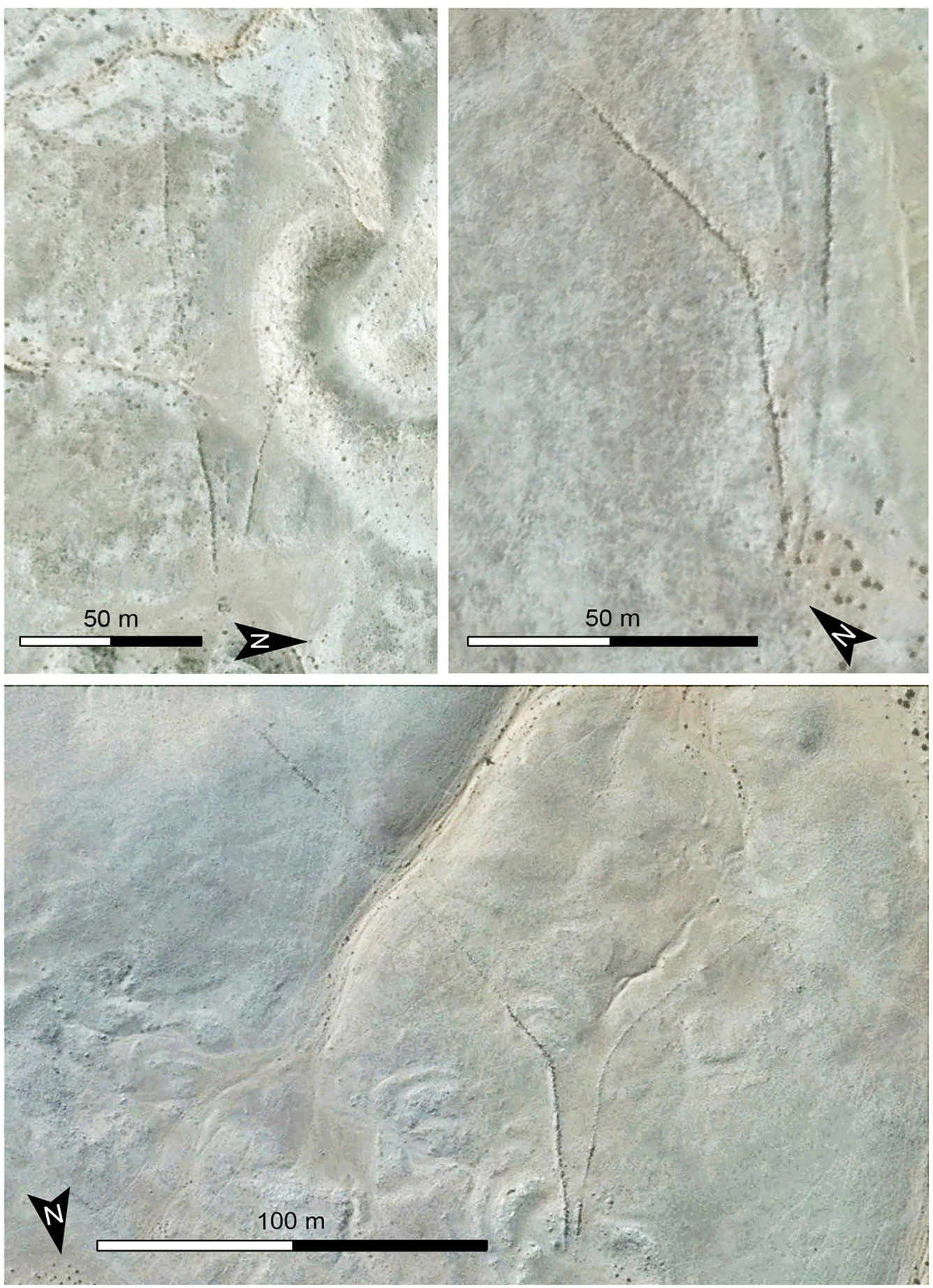

Figure 3. Three examples of guiding systems; top left) symmetrical cone antennae; top right) asymmetrical funnel antennae; bottom) symmetrical funnel antennae (images (C) Google Earth). 

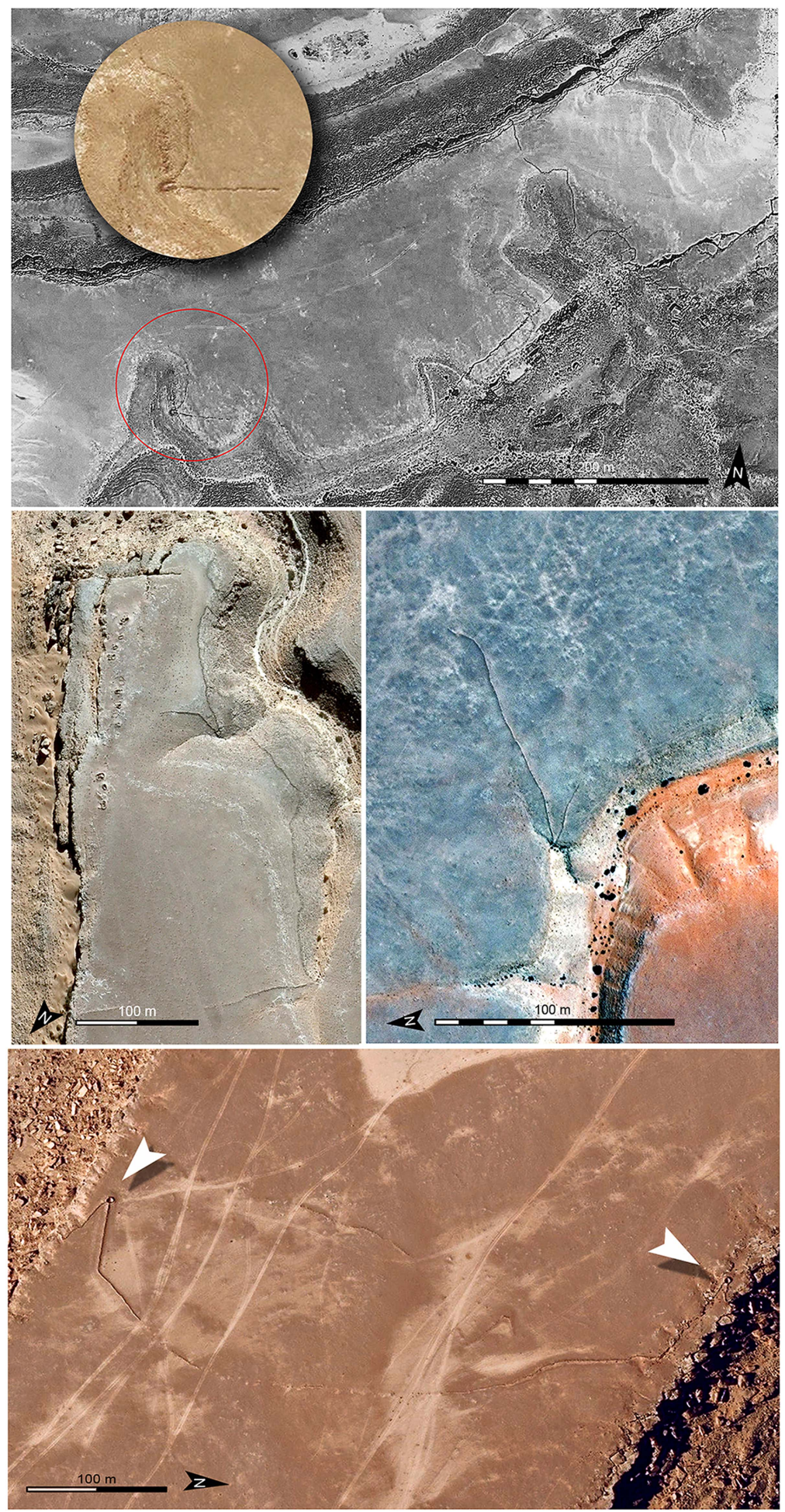

Figure 4. Three chute structures; top) structure with artificial embankment at the slope base, at the convergence of the antennae; centre leftright) the same embankment is not visible in these two sites; bottom) system with two circular pits at the edge of the promontory (white arrows) (images (C) Google Earth).

(C) Antiquity Publications Ltd, 2018 

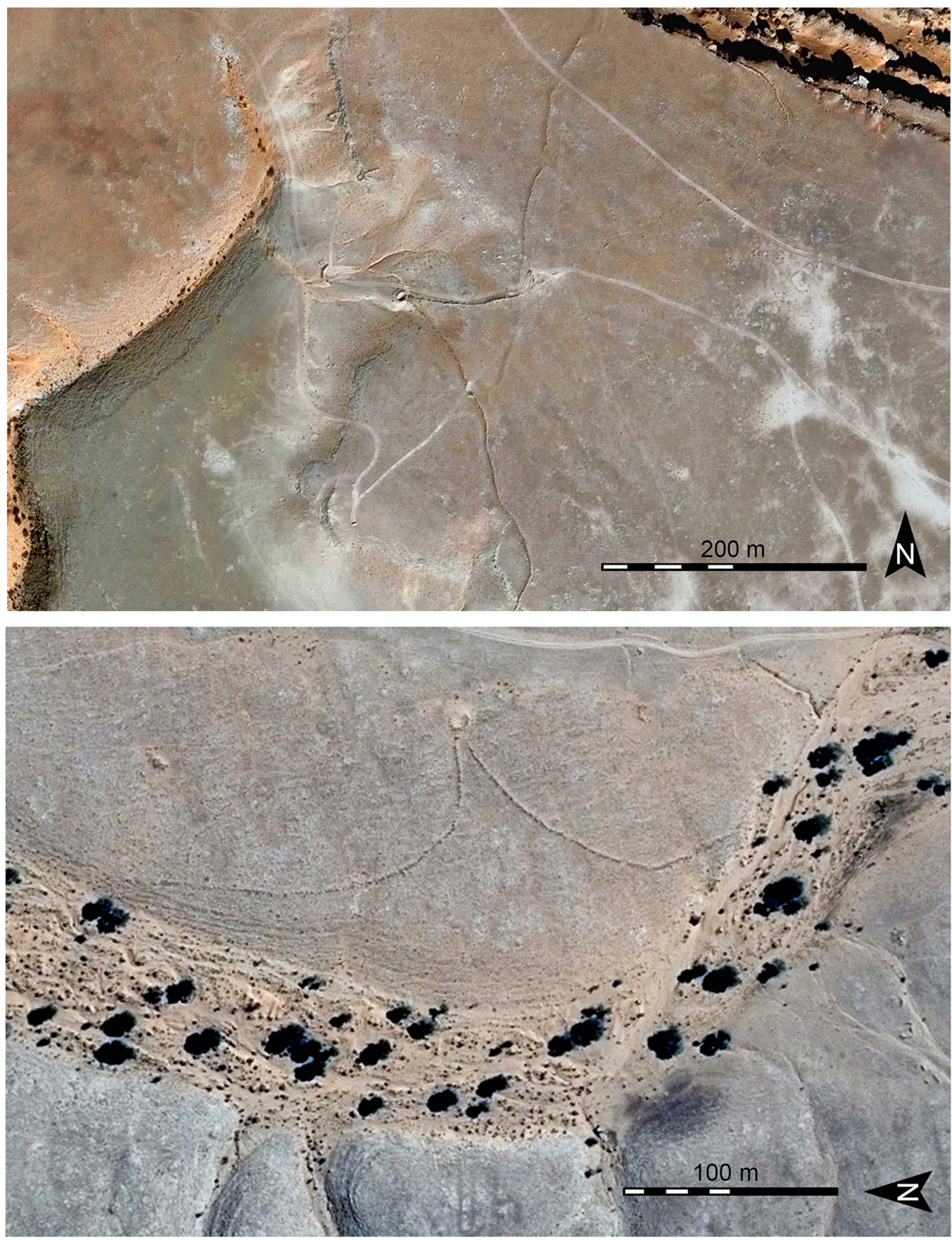

Figure 5. Top) long antennae of the kite to drive prey into a large pit on a slope. The remains of a small circular structure of unknown function are visible to the north; bottom) the antennae connecting the wadi shore to the circular pit are in a raised position (images (C) Google Earth). 


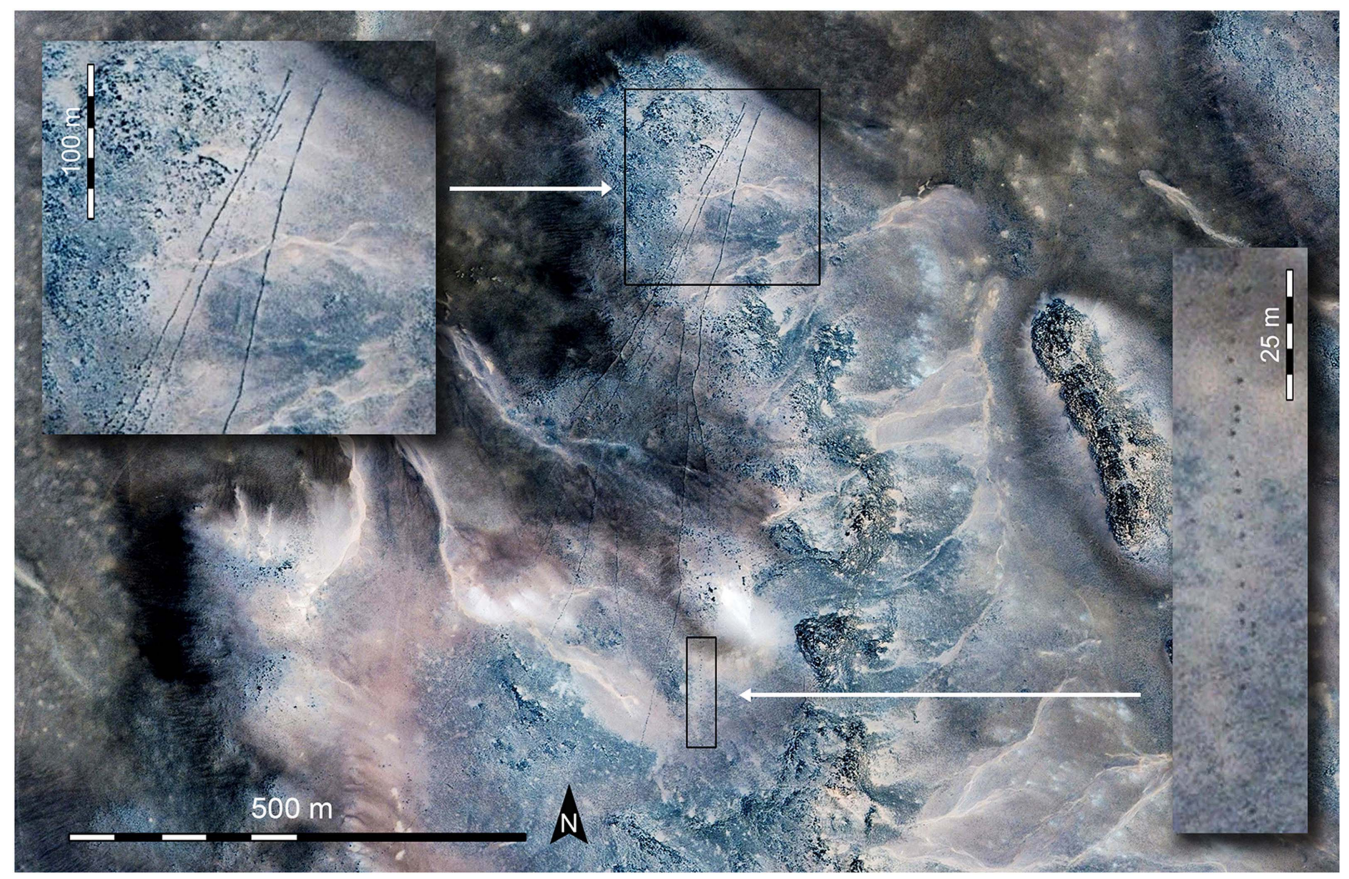

Figure 6. The long channelling antennae are clearly visible on the basalt floor. The enlarged frame shows a section of the wall formed by a non-continuous alignment of stones (images (C) Google Earth).

approximately circular pits $5 \mathrm{~m}$ in diameter (Figure 4: bottom). Another system has a pit on slightly sloping ground, which was probably invisible to the approaching prey (Figure 5: top). A further example was built at the edge of a wadi (Figure 5: bottom), presumably to capture animals that gathered near the river-as at the Jordanian site of Saudi Harrat Ash Shaam (Betts \& Burke 2015). Forty-four structures have been identified to the south-east, 23 of which are distributed for approximately $30 \mathrm{~km}$ in a north-south direction. They appear as subtle, long, dark lines, probably made of local volcanic stone. They are lacking an apex enclosure as seen in the Yemen kites located between the Ma'rib and Sirwâ regions (Brunner 2008; Skorupka 2010). The antennae range in length from $120-800 \mathrm{~m}$, while the space between the two arms at the end of the convergence fluctuates between 15 and $20 \mathrm{~m}$ (Figure 6). The lack of a fence could cast doubt over the use of these structures for hunting. One could therefore cautiously hypothesise that at the apex of the stone lines' convergence there were complementary systems consisting of nets or shrubs to capture animals—as documented in rock art and ethnographically in other areas of Africa (Le Quellec \& Civrac 2010).

\section{Conclusions}

The typology of these Libyan systems raises intriguing questions about their origin and diffusion, about the communities that used them and the variety of prey hunted. Studies should also consider the so-called 'game traps' reported in Egypt in Lower Nubia, the Great

(C) Antiquity Publications Ltd, 2018 
Sand Sea, Jebel Uweinat and Gilf Kebir, to understand the technical evolution of Northern African hunting systems. The distribution of kites on the Hamada al Hamra Plateau suggests regionalisation of the different structure types, probably attributable to geomorphological factors, the species and quantity of animals being captured and the attitudes and periodic movements of those animals. Finally, the choice of construction sites demonstrates a profound knowledge of the region, both at a large scale and at the local level. Consequently, the structures, which involved planning, organisation and realisation phases, became a marker for territorial ownership. Based on the results of this investigation phase, we are now analysing other regions of Libya. The initial findings are relevant and unexpected, and will be published in the near future.

\section{References}

Barge, O., J.É. Brochier, J.M. Deom, R. Sala, A. Karakhanyan, A. Aavagyan \& K. Plakhov. 2016. The 'desert kites' of the Ustyurt Plateau. Quaternary International 395: 113-32. https://doi.org/10.1016/j.quaint.2015.06.010

Bar-Oz, G., D. Nadel, U. Avner \& D. Malkinson. 2011. Mass hunting game traps in the southern Levant: the Negev and Arabah 'Desert Kites'. Near Eastern Archaeology 74: 208-15. https://doi.org/10.5615/neareastarch.74.4.0208

Betts, A.V.G. \& D. Burke. 2015. Desert kites in Jordan-a new appraisal. Arabian Archaeology and Epigraphy 26: 74-94. https://doi.org/10.1111/aae.12062

Betts, A.V.G. \& V.N. Yagodin. 2000. Hunting traps on the Ustiurt Plateau, Uzbekistan, in D. Christian \& C. Benjamin (ed.) Realms of the Silk Roads: ancient and modern Silk Road studies: 2945. Turnhout: Brepols.

BRUnNer, U. 2008. Les pièges de chasse antiques au Yémen. Chroniques Yéménites 15: 29-34.
Holzer, A., U. Avner, N. Porat \& L. KolskaHorwitz. 2010. Desert kites in the Negev Desert and northeast Sinai: their function, chronology and ecology. Journal of Arid Environments 74: 806-17. https://doi.org/10.4000/cy.1666

Le Quellec, J. \& M. Civrac. 2010. La chasse au filet sur les peintures rupestres du Sahara central et dans l'Antiquité. Les Cahiers de l'AARS 10: 255-62.

Nadel, D., G. Bar-Oz, U. Avner, E. Boaretto \& D. Malkinson. 2010. Walls, ramps and pits: the construction of the Samar desert kites, southern Negev, Israel. Antiquity 84: 976-92. https://doi.org/10.1017/S0003598X00067028

Nadel, D., G. Bar-Oz, U. Avner, D. Malkinson \& E. BoAretto. 2013. Ramparts instead of walls: building techniques of large game traps (kites) in the Negev highland. Quaternary International 297: 147-54. https://doi.org/10.1016/j.quaint.2012.11.037 SкоRupка, M. 2010. Les 'desert kites' yéménites. Chroniques yéménites 16: 5-14. 